\title{
Sudden onset of severe anterior knee pain and knee locking during sleep
}

\author{
Žiga Snoj ${ }^{1} \cdot$ Jože Pižem ${ }^{2} \cdot$ Vladka Salapura $^{1}$
}

Published online: 14 November 2015

(C) ISS 2015

\section{Discussion}

In 2013, the WHO revised the terminology for the family of lesions previously described as giant cell tumor of the tendon sheath and pigmented villonodular synovitis. The correct current terminology is tenosynovial giant cell tumors, further subclassified by the extent (localized or diffuse) and location (intra- or extraarticular) [1]. Intraarticular lesions are usually monoarticular and usually affect the knee [2]. The localized intraarticular lesion was formerly termed as localized pigmented villonodular synovitis. The diffuse intraarticular diffuse type affects the entire joint synovium, and patients typically present with a long history of pain, swelling, restricted movement and occasional hemarthrosis [2, 3]. Localized intraarticular tenosynovial giant cell tumor is characterized by limited involvement of the synovium presenting as an intraarticular nodule or mass, which can result in mechanical symptoms, including locking, as presented in our case [2, 4]. Localized intraarticular tenosynovial giant cell tumor of the knee is usually located in the meniscocapsular junction, anterior tibial eminence, intercondylar notch region or lateral recesses. It is rarely located in the fat pad, medial femoral condyle, mediopatellar synovial plica or inside a popliteal cyst $[2$,

The case presentation can be found at doi:10.1007/s00256-015-2287-1.

Answer Intraarticular localized tenosynovial giant cell tumor:

Vladka Salapura

salapura@siol.net

1 Institute of Radiology, University Medical Centre Ljubljana, Zaloska 7, 1000 Ljubljana, Slovenia

2 Institute of Pathology, Medicine Faculty Ljubljana, Korytkova 2, 1000 Ljubljana, Slovenia
3]. Infrequently, the pedicle can be subject to torsion, resulting in tumor infarction [2].

Our patient suffered from sudden knee pain with movement limitation. A radiograph revealed a persistent secondary ossification center of the tibial tuberosity; however, this was considered irrelevant to his clinical symptoms (Fig. 1 testyourself question). An immediate MR imaging examination confirmed a nodular lesion in the anterior aspect of the femorotibial joint, which was predominantly hypointensive on PD and PD fat-suppressed images, with profoundly hypointensive signal on GRE images (Fig. 2 test-yourself question), consistent with a hemosiderin-laden lesion [4-6]. Additional MR imaging sequences were performed the following morning after resolution of the patient's symptoms, presumed to be due to spontaneous relocation of the nodule, for further lesion characterization and included $\mathrm{T} 1 \mathrm{~W}, \mathrm{~T} 2 \mathrm{~W}$ and enhanced fat-suppressed T1W images (Fig. 3 testyourself question). Decreased signal intensity was again seen with a prominent peripheral rind of enhancement and mild inner enhancement $[2,4,5,7]$. The diagnosis of intraarticular localized tenosynovial giant cell tumor was suggested, and the mass was subsequently removed arthroscopically [2, 3, 7]. Arthroscopy confirmed a pedunculated lesion arising beneath the synovial surface with histology demonstrating synoviallike mononuclear cells, scattered osteoclast-like cells, siderophages and areas of hemosiderin deposition (Fig. 4 test-yourself question).

As described, localized intraarticular tenosynovial giant cell tumor can present with transient knee locking, which typically suggests a differential diagnosis that includes meniscal lesions, chondral lesions and loose bodies [2, 7]. MR imaging was indispensable in this case, showing a hemosiderin-laden nodule in Hoffa's fat. Localized intraarticular lesions such as synovial hemangioma, synovial lipoma, ganglion, a multifocal synovial chondromatosis or primary intraarticular 
malignancy may arise at Hoffa's fat $[2,4,6]$. MR imaging features in diffuse intraarticular tenosynovial giant cell tumor may resemble rheumatoid or hemophilic arthropathies [6]. Histopathological diagnosis of tenosynovial giant cell tumor is strongly advised and straightforward [2, 7, 8]. The treatment of localized intraarticular tenosynovial giant cell tumor is a complete nodular excision by arthroscopy or arthrotomy [4, $7,9]$. Diffuse intraarticular tenosynovial giant cell tumor requires extensive synovectomy, possibly combined with radiotherapy $[4,10]$. The recurrence rate in localized disease is less than $5 \%$; however, in diffuse disease the recurrence rate ranges from 25 to $50 \%[2-4,7]$.

\section{References}

1. De Saint AubainSomerhausen N, van de Rijn M. Tenosynovial giant cell tumour, localized type. In: Fletcher CDM, Bridge JA, Hogendoorn P, Mertens F, editors. World Health Organization classification of tumours of soft tissue and bone. 4 th ed. Lyon: IARC Press; 2013. p. 100-1.

2. Calmet J, Hernández-Hermoso J, Giné J, Jimeno F. Localized pigmented Villonodular synovitis in an unusual location in the knee. Arthroscopy. 2003;19:144-9.
3. Kim RS, Kang JS, Jung JH, Park SW, Park IS, Sun SH. Clustered localized pigmented villonodularsynovitis. Arthroscopy. 2005;21: 761.

4. Huang GS, Lee CH, Chan WP, Chen CY, Yu SJ, Resnick D. Localized nodular synovitis of the knee: MR imaging appearance and clinical correlates in 21 patients. AJR. 2003;181:539-43.

5. Wan JMC, Magarelli N, Peh WCG, Guglielmi G, Shek TWH. Imaging of giant cell tumor of the tendon sheath. Radiol Med. 2010;115:141-51.

6. Narvaez JA, Narvaez J, Ortega R, De Lama E, Roca Y, Vidal N. Hypointense synovial lesions on T2-Weighted Images: differential diagnosis with pathologic correlation. AJR. 2003;181:761-9.

7. Hantes ME, Basdekis GK, Zibis AH, Karantanas AH, Malizos KN. Localized pigmented villonodularsynovitis in the anteromedial compartment of the knee associated with cartilage lesions of the medial femoral condyle: report of a case and review of the literature. Knee Surg Sports Traumatol Arthrosc. 2005;13:209-12.

8. Dodd LG, Bui MM. Tenosynovial Giant Cell Tumors. In: Dodd LG, Bui MM, editors. Atlas of Soft Tissue and Bone Pathology: With Histologic, Cytologic and Radiologic Correlations. New York, NY: Demos Medical Publishing; 2015. P.203-7.

9. Dines JS, DeBerardino TM, Wells JL, Dodson CC, Shindle M, DiCarlo EF, et al. Long-term follow-up of surgically treated localized pigmented villonodularsynovitis of the knee. Arthroscopy J Arthrosc Relat Surg. 2007;23:930-37.

10. Blanco RCE, Leon H, Guthrie TB. Combined partial arthroscopic synovectomy and radiation therapy for diffuse pigmented villonodularsynovitis of the knee. Arthroscopy J Arthrosc Relat Surg. 2001;17:527-31. 